\title{
Genetic Variability Studies in Genetically Diverse Rice Genotypes
}

\author{
J. Divya $^{1 *}$, Ch. Damodar Raju ${ }^{1}$, L.V. Subba Rao ${ }^{2}$ and K. Aparna ${ }^{3}$ \\ ${ }^{1}$ Rice Research Centre, ARI, PJTSAU, Rajendranagar, Hyderabad-500030, Telangana, India \\ ${ }^{2}$ Crop Improvement Section, Indian Institute of Rice Research, Rajendranagar, \\ Hyderabad-500030, Telangana, India \\ ${ }^{3}$ Quality Control Laboratory, PJTSAU, Rajendranagar, Hyderabad-500030, Telangana, India \\ *Corresponding author
}

A B S T R A C T

\begin{tabular}{|c|c|}
\hline Keywords & \multirow{4}{*}{$\begin{array}{l}\text { The experiment was conducted in randomized complete block design with two replications } \\
\text { during Kharif } 2016 \text { at Rice Research Centre, Agricultural Research Institute, } \\
\text { Rajendranagar, Hyderabad. A total of thirty three genetically diverse genotypes were } \\
\text { considered for the study. Analysis of variance was found to be significant for all the traits, } \\
\text { indicate that there is existence of genetic variability for all the traits varying from lower to } \\
\text { higher coefficients of variance. The results found that the moderate genotypic and } \\
\text { phenotypic coefficients of variance were recorded for number of productive tillers per } \\
\text { plant, number of grains per panicle and seed yield per plant. High heritability with high } \\
\text { genetic advance was observed for number of productive tillers per plant, } 1000 \text { grain } \\
\text { weight, number of grains per panicle and seed yield per plant. The traits were found to } \\
\text { have higher values of variance and selection for such traits will be practiced based on } \\
\text { phenotypic observation. }\end{array}$} \\
\hline & \\
\hline Articl & \\
\hline & \\
\hline
\end{tabular}

\section{Introduction}

Rice is a staple food for millions of people and having great importance in food and nutritional security. It is the second most widely consumed in the world next to wheat. From poorest to richest person in this world consume rice in one or other form.

Development of high yielding genotypes under such conditions require a thorough knowledge of genetic variation and yield contributing characters, the observed variability is a combined estimate of genetic and environmental causes whereas genetic variability alone is heritable. Moreover the estimate of genetic variability across the environments with in the conditions, however result in a favorable environment to exploit complete genetic variability to exercise selection for development of yield contributing traits.

An estimate of heritability alone does not give an idea expected genetic gain in the next generation but also is considered in the conjunction with genetic advance [1-5]. Therefore, the present Investigation was made with an objective to identify the elite genotypes for yield and quality parameters. 


\section{Materials and Methods}

The experimental material consisted of thirty three genotypes. Field trial were laid out in a Randomized Block Design with three replication in the spacing of $20 \mathrm{~cm} \times 15 \mathrm{~cm}$ at kharif, 2016 at Rice Research Centre, Agricultural Research Institute, Rajendranagar, Hyderabad and the recommended culture practices were carried out. The observation on characters like days to $50 \%$ flowering, plant height, number of productive tillers per hill, panicle length, number of grains per panicle, test weight and seed yield per plant. The data were analyzed by using ANOVA and genetic parameters such as PCV and GCV, heritability in broad sense $\left(h^{2}\right)$, and genetic advance in percent of mean were calculated.

\section{Results and Discussion}

Analysis of variance revealed highly significant differences among the genotypes for the entire test characters, indicating the existence of high variability among the varieties (Table 1). Thus, there ample scope for selection of different quantitative characters for rice improvement. The estimate of phenotypic coefficient of variation, genotypic coefficient of variation, heritability and genetic advance as percent mean were obtained for different characters and they are presented in Table 2.

The phenotypic coefficient of variation values are lightly higher than genotypic coefficient variation indicating less influence of environment on these traits.

The results found that the moderate genotypic and phenotypic coefficients of variance were recorded for number of productive tillers per plant, number of grains per panicle, seed yield per plant. Low genotypic and phenotypic coefficients of variance were recorded for days to $50 \%$ flowering, plant height, panicle length.

These results were confirmed with the finding of Rajender et al., (2013) for days to 50\% flowering, plant height, Sravan et al., (2012) for days to $50 \%$ flowering, number of productive tillers per plant and number of grains per panicle, Sameera et al., (2015) for plant height and panicle length, Pandey et al., (2012) for number of grains per panicle and seed yield per plant.

Table.1 Analysis of variance for yield, its component characters and quality parameters

\begin{tabular}{|c|c|c|c|}
\hline \multirow[t]{2}{*}{ Characters } & \multicolumn{3}{|c|}{ Source of variation } \\
\hline & $\begin{array}{l}\text { Replications } \\
(\text { d.f. = 2) }\end{array}$ & $\begin{array}{l}\text { Treatments } \\
(\text { d.f. }=32)\end{array}$ & $\begin{array}{l}\text { Error } \\
(\text { d.f. }=64)\end{array}$ \\
\hline Days to $50 \%$ flowering & 0.919 & $123.732 * *$ & 1.034 \\
\hline Plant height $(\mathrm{cm})$ & 0.079 & $202.366^{* *}$ & 0.079 \\
\hline No, of effective tillers per plant & 0.125 & $17.691 * *$ & 0.1 \\
\hline Panicle length $(\mathrm{cm})$ & 0.072 & $9.578 * *$ & 0.142 \\
\hline 1000 grain weight $(\mathrm{g})$ & 0.014 & $24.468 * *$ & 0.223 \\
\hline No of grains per panicle & 0.657 & $4151.975^{* *}$ & 49.363 \\
\hline Seed yield per plant (g) & 0.07 & $20.279 * *$ & 1.853 \\
\hline
\end{tabular}


Table.2 Estimates of variability, heritability and genetic advance for yield, its component characters and quality parameters

\begin{tabular}{|c|c|c|c|c|c|c|c|c|c|}
\hline \multirow[t]{2}{*}{ Characters } & \multirow[t]{2}{*}{ Mean } & \multicolumn{2}{|c|}{ Range } & \multirow{2}{*}{$\begin{array}{l}\text { Phenotypic } \\
\text { Variance }\end{array}$} & \multirow{2}{*}{$\begin{array}{l}\text { Genotypic } \\
\text { Variance }\end{array}$} & \multirow{2}{*}{$\begin{array}{l}\text { PCV } \\
(\%)\end{array}$} & \multirow{2}{*}{$\begin{array}{l}\text { GCV } \\
(\%)\end{array}$} & \multirow{2}{*}{$\begin{array}{l}\text { Heritability in } \\
\text { broad sense }\left(\mathrm{h}^{2}\right) \\
(\%)\end{array}$} & \multirow{2}{*}{$\begin{array}{l}\text { Genetic } \\
\text { Advance } \\
(5 \%)\end{array}$} \\
\hline & & Min & Max & & & & & & \\
\hline Days to $50 \%$ flowering & 109.38 & 92.33 & 119 & 41.93 & 40.89 & 5.92 & 5.84 & 97.5 & 11.89 \\
\hline Plant height $(\mathrm{cm})$ & 94.54 & 75.95 & 119.15 & 67.50 & 67.42 & 8.69 & 8.68 & 99.9 & 17.88 \\
\hline No, of effective tillers per plant & 14.56 & 10.61 & 18.95 & 5.96 & 5.86 & 16.77 & 16.63 & 98.3 & 33.97 \\
\hline Panicle length $(\mathrm{cm})$ & 22.26 & 16.40 & 25.80 & 3.28 & 3.14 & 8.14 & 7.96 & 95.7 & 16.05 \\
\hline 1000 grain weight $(\mathrm{g})$ & 18.33 & 12.64 & 24.81 & 8.30 & 8.08 & 15.71 & 15.50 & 97.3 & 31.50 \\
\hline No, of grains per panicle & 190.39 & 94.41 & 250.74 & 1416.90 & 1367.53 & 19.77 & 19.42 & 96.5 & 39.30 \\
\hline Seed yield per plant (g) & 21.76 & 14.93 & 25.18 & 7.99 & 6.14 & 12.99 & 11.38 & 76.8 & 20.56 \\
\hline
\end{tabular}

Min.-Minimum, Max.-Maximum, PCV- Phenotypic Coefficient of Variation; GCV- Genotypic Coefficient of Variation 
Heritability is a measure of extent of phenotypic variation caused by the action of genes. For making effective improvement in the characters for which selection is practiced, heritability has been adopted by genetic variability, which is transmitted from parent to offspring is reflected by heritability.

The estimate of heritability alone is not very much useful on predicting resultant effect for selecting the best individual because it includes the effect of both additive gene as well as non-additive gene.

High genetic advance only occurs due to additive gene action. So heritability coupled with genetic advance would be more useful than heritability alone.

In the present study high heritability coupled with high genetic advance was observed for traits for number of productive tillers per plant, 1000 grain weight, number of grains per panicle, seed yield per plant. High heritability coupled with moderate genetic advance were recorded for days to $50 \%$ flowering, plant height and panicle length.

These results were confirmed with the finding of Rajender et al., (2013) for days to 50\% flowering, Patel et al., (2014) plant height, Sravan et al., (2012) for number of grains per panicle, Sameera et al., (2015) for number of productive tillers, seed yield per plant.

Pandey et al., (2012) for seed yield per plant, Singh et al., (2011) for days to $50 \%$ flowering, panicle length and number of grains per panicle.

\section{References}

Pandey, V.R., Singh, P.K., Verma, O.P and Pandey, P. 2012. Inter-relationship and path coefficient estimation in rice under salt stress environment. International Journal of Agricultural Research. 7: 169-184.

Patel, J.R., Saiyad, M.R., Prajapati, K.N., Patel, R.A and Bhavani R.T. 2014. Genetic variability and character association studies in rainfed upland rice (Oryza sativa L.) Electronic Journal of Plant Breeding. 5(3): 531537.

Rajendar Reddy, M., Surendar Raju, Ch., Dayakar reddy, T. and Narender reddy. S. 2013. Study on genetic parameters in $\mathrm{F} 2$ generation involving aromatic rice genotypes (Oryza sativa L.). International Journal of Applied Biology and Pharmaceutical Technology. 4 (4): 238-241.

Sameera, S.K., Rajesh, A.P., Jayalakshmi, V., Nirmala, P.J and Srinivas. T. 2015. Genetic variability studies for yield and yield components in rice (oryza sativa L.) Electronic Journal of Plant Breeding. 6 (1): 269-273.

Singh, S.K., Singh, C.M and Lal, G.M. 2011. Assessment of genetic variability for yield and its component characters in rice (Oryza sativa L.). Research in Plant Biology. 1 (4): 73-76.

Sravan, T., Rangare, N.R., Sursh, B.G and Kumar, S.R., 2012. Genetic variability and character association in rainfed upland rice (Oryza sativa L.). Journal of Rice Research. 5 (1 and 2): 24-29.

\section{How to cite this article:}

Divya, J., Ch. Damodar Raju, L.V. Subba Rao and Aparna, K. 2018. Genetic Variability Studies in Genetically Diverse Rice Genotypes. Int.J.Curr.Microbiol.App.Sci. 7(04): 11691172. doi: https://doi.org/10.20546/ijcmas.2018.704.129 